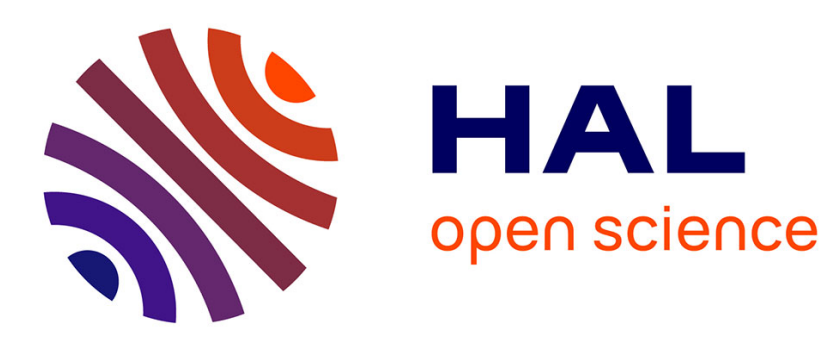

\title{
Breaking Up the Family: Divorce in Egyptian Law and Practice
}

\author{
Nathalie Bernard-Maugiron, Baudouin Dupret
}

\section{To cite this version:}

Nathalie Bernard-Maugiron, Baudouin Dupret. Breaking Up the Family: Divorce in Egyptian Law and Practice. Hawwa, 2008, 6, pp.52-74. halshs-00339503

\section{HAL Id: halshs-00339503 \\ https://shs.hal.science/halshs-00339503}

Submitted on 18 Nov 2008

HAL is a multi-disciplinary open access archive for the deposit and dissemination of scientific research documents, whether they are published or not. The documents may come from teaching and research institutions in France or abroad, or from public or private research centers.
L'archive ouverte pluridisciplinaire HAL, est destinée au dépôt et à la diffusion de documents scientifiques de niveau recherche, publiés ou non, émanant des établissements d'enseignement et de recherche français ou étrangers, des laboratoires publics ou privés. 


\title{
Breaking-off the Family: Divorce in Egyptian Law and Practice
}

\author{
By Nathalie Bernard-Maugiron, IRD, UR102, Cairo, Egypt \\ with the collaboration of Baudouin Dupret, CNRS, ISP, Cachan, \\ France
}

From the twentieth century onward, Egyptian law-makers strived to re-instate a balance between men and women in their access to breaking-off the marriage. The legislature started interfering in new fields to favor the adaptation of law to the evolution of society and to find solutions to social problems it was confronted with. ${ }^{1}$ The study of the explanatory notes of the laws discloses this very spirit.

The outcome of those reforms is, however, mitigated. No doubt women's status in divorce has improved, but it remains very unequal in comparison to men. These latter can unilaterally sever spousal relationships by means of repudiation, even if the legislature has interfered, here too, to insert this means of breaking-off in a tight legal framework. Moreover, the practical effect of these judicial reforms is in question.

The study of breaking-off marriage in Egypt must therefore be carried out through two approaches, one legal and the other sociological. The legal dimension will be addressed through examining the legal texts that govern family laws, as well as their explanatory notes. The second part will be dedicated to the implementation of those norms, including before the courts, and to the various obstacles that impede the effective implementation of reforms. ${ }^{2}$

\section{Breaking off Marriage: Law in the Books}

Legally speaking, breaking-off marriage can take place at the initiative of either spouse. In both cases, the codification process lead to some improvement in women's status.

\section{A. Breaking off Marriage at the Wife's Initiative: the Divorce}

The right to divorce was elaborated in three stages: first of all, the laws of 1920 and 1929 allowed divorce for various forms of damages; then those of 1979 and 1985 dealt with the particular case of divorce for the harm caused by the husband's polygamy; finally, a

\footnotetext{
${ }^{1}$ This article deals only with personal status law for Muslims.

${ }^{2}$ For a study of the normative implementation of family law in Egypt see Ahmed al-Sâwî (ed.), The Harvest. Two Years after Khul', CEWLA, Cairo, 2003 (in Arabic); Nâdia Halîm, Social Effects of Khul', Center for Egyptian Women Legal Assistance (CEWLA), Cairo, 2006 (in Arabic) and Essam Fawzy, "Muslim Personal Status Law in Egypt : the Current Situation and Possibilities of Reform through Internal Initiatives », in Lynn Welchman (ed.), Women's Rights and Islamic Family Law : Perspectives on Reform, Zed Books, London, New York, 2004.
} 
law adopted in 2000 introduced a judicial procedure for the breaking-off of marriage without harm.

\section{Laws of 1920 and 1929: Divorce for Harm Inflicted}

The Egyptian legislature, in the 1920s, authorized women to ask for judicial divorce when it is proved that they suffer from one of the harms stipulated in the law. Such a reform was justified by referring to some principles adopted by various Sunni religious legal schools, showing its will to re-establish a certain balance between the two spouses.

The Hanafi School of law, traditionally applied in Egypt, hardly acknowledges the husband's impotency or castration as reasons for legal dissolution of spousal bonds. In particular, as recalled in the explanatory note of the Decree-Law No. 25/1929 concerning some questions related to personal status: "No opinion in the Abû Haniffa doctrine provides women with the means to exit marriage or foresees any way to bring back the husband on the right path. Each one can harm the other out of vengeance." This discord between spouses "is a source of harm which hurts not only the spouses, but also their offspring, parents, and in-laws." In order to avoid the crimes and sins provoked by this disharmony between spouses, the Ministry deemed that "the welfare commands to adopt Imam Mâlik's doctrine in case of discord between spouses." If the Mâliki doctrine agrees to give women the divorce on certain grounds, the Hanafi doctrine, on the contrary, does not consider the harm the wife suffers as reasons for divorce, since it could be dealt with by other means like reprimanding the husband or the wife's refusal to obey him.

In the same text, the legislature justified having recourse to the Mâliki doctrine to authorize women to ask for divorce in case of the husband's extended absence, ${ }^{3}$ out of fear for the abandoned wife's honor and chastity. As underlined in the explanatory note of Decree-Law No. 25/1929, "the Hanafî doctrine brings no remedy in such cases, whereas bringing a remedy constitutes a pressing social obligation." If the Hanafi School has not foreseen such a case, in return, "the Mâliki allows the judge to issue the divorce when the husband is absent for more than one year and when the woman complains of his absence, even if he has property from which she can get her maintenance." Also the introduction of divorce possibilities for failure to provide maintenance ${ }^{4}$ by the nonabsent $^{5}$ or imprisoned ${ }^{6}$ husband is equally of Mâliki inspiration. The legislature justified in its explanatory note this last case of enabling divorce, by the wish to protect women from risks of adultery: "It is against nature that a woman live alone and preserve intact her honor and honesty" and "What matters is the harm suffered by the wife because of her husband's distance from her, whether it is willful or not on his behalf".

\footnotetext{
${ }^{3}$ The wife can ask for the divorce in case the husband's absence is prolonged more than a year without any legitimate motive, even if the husband has left goods on which she can debit maintenance expenditure. See Decree-Law No. 25/1929, art. 12 and 13.

${ }^{4}$ The husband has a maintenance obligation toward his wife for the entire duration of marriage, including when the wife has personal resources.

${ }^{5}$ Law No. 25/1920 concerning maintenance and some other questions of personal status, art. 4.

${ }^{6}$ The wife can also ask for the divorce if her husband is condemned to jail for more than three years, even if he has property from which she could get maintenance; see Decree-Law No. 25/1929, art. 14.
} 
The wife can equally ask to break marriage off in case of the husband's suffering from serious and incurable defect, if such a defect makes life together harmful to the woman. She could not, however, invoke this grievance had it been present before marriage and had she been aware of it, or if such a disease appeared after marriage but she accepted it, expressly or tacitly. ${ }^{7}$

Decree-Law No. 25/1929 has foreseen another reason for divorce, more general, which is divorce for harm

If the wife pretends that she suffered harm from her husband, which make impossible continuation of life between persons of their condition, she can ask the judge to divorce her. The judge will issue an irrevocable judgment of divorce in her favor, when such harm is proved and he could not reconcile the spouses $(\ldots) .^{8}$

It will be the wife's responsibility to substantiate before the judge the injury inflicted upon her by her husband that renders life between persons of their condition impossible. The judge will have, on ad hoc basis, to assess at his discretion the existence or not of such harm. Such assessment could vary on a case-by-case basis, contingent upon circumstances and according to the subjective assessment of the judge. The assessment criteria of the degree of injury will depend, in addition, on the social status of both spouses. Some acts, considered harmful in some social levels, will not necessarily be considered so by the judge for some other social strata. This reason for divorce is also inspired by the Mâliki School as is underlined by the explanatory note of the Decree-Law No. $25 / 1929$.

To prove the harm and in particular the bad treatment inflicted by her husband, the woman will have to present two witnesses having seen and heard by themselves the acts blamed on the husband. Such testimonies will be subject to the unconstrained assessment of the judge who is not bound to grant the divorce. The proof of harm is then difficult to avail, especially when it is about a moral harm. Physical violence often takes place in the bedroom, far from any external witnesses.

In practice, it seems that the grounds most frequently referred to by women to get the divorce are the lack of maintenance or the husband's absence. ${ }^{9}$

\section{Laws of 1979 and 1985: the Polygamous Husband}

The laws of 1920 and 1929 remained unchanged for more than half a century. Only in 1979 did President Sadat issue Decree-Law No. 44 amending those two texts. Among the new provisions introduced was the requirement that the husband's remarrying without the first wife's consent (or first wives) be considered harmful as such and that the first wife be granted automatic divorce by the judge, provided she so requested within a year from the day she got to know of his marriage. ${ }^{10}$ The simple fact that her husband got remarried was thus presumed harmful and she could get automatically divorced before the courts,

\footnotetext{
${ }^{7}$ Law No. 25/1920, art. 9.

${ }^{8}$ Decree-Law No. 25/1929, art. 6.

${ }^{9}$ For the motives invoked before the Shari' a courts prior to their abolition, see Shaham, R., Judicial

Divorce at the Wife's Initiative: the Shari 'a Courts in Egypt, 1920-1955, Islamic Law and Society, 1994.

${ }^{10}$ Art. 6 bis $1 \S 2$ added to Decree-Law No. 25/1929.
} 
without the need to prove the harm inflicted. This law was criticized and challenged as constituting an indirect restriction to polygamy which, since it is legally and religiously legitimate, should not be considered as harm for the first wife. Many personal status judges refused to apply this provision and referred it to the Supreme Constitutional Court on the pleas that it violated the Islamic shari ' $a$ whose principles, according to Article 2 of the Constitution, are the main source of legislation.

Decree-Law No. 44/1979 was finally declared unconstitutional in 1985, but on procedural grounds: the Supreme Constitutional Court judged that using the decree-law procedure, which permits the President of the Republic to legislate in the Parliament's absence for urgent matters, was not justified to amend laws dating back to 1920 and 1929. ${ }^{11}$ The new law, adopted two months after the decision of unconstitutionality, still authorized the wife to divorce her husband for polygamy, but required the wife to prove that her husband's remarriage had caused her material or moral harm, so that it made continued married life impossible. ${ }^{12}$ The wife has a one-year grace period from the date she got to know of her husband's remarriage to ask for divorce, unless she has consented explicitly or tacitly. ${ }^{13}$ Since any new marriage must be registered and the previous wife must be notified, she should be informed of her husband's second marriage. ${ }^{14}$

If Law No. 100/1985 now mentions polygamy as a possible source of harm, the situation, though is, close to that which prevailed under Decree-Law No. 25/1929: a woman can get a divorce for the harm inflicted by a polygamous husband, but the burden of proof lies on her to substantiate the harm suffered. The judge will have a discretionary power to assess the evidence, on the basis of testimonies by witnesses. The explanatory note maintains that the 1985 Law does not aim to restrict the husband's right to polygamy, but to offer a remedy to the first wife who would be damaged by her husband's remarriage. ${ }^{15}$

The Egyptian legislature has, therefore, allowed the woman to get a divorce on grounds of various grievances, but the request remains subjugated to the judge's discretionary power of assessment. Moreover, the wife needs to provide at least two witnesses to prove that she suffered harm, whatever its kind. Last but not least, the procedure is often lengthy and costly and the wife has not even a guarantee, after all those years, that her marriage will be broken off.

\section{Law of 2000: Divorce without Harm (Khul')}

To fight against the court backlogs and its lengthy divorce procedures, the legislature offered women in 2000 the possibility of breaking off marriage automatically by a procedure called $k h u l$, in return for forsaking their financial rights.

\footnotetext{
${ }^{11}$ Supreme Constitutional Court (SCC), 4 May 1985, No. 28/2.

${ }^{12}$ Decree-Law No. 25/1929, art. 11 bis 1, as added by Law No. 100/1985.

${ }^{13} \mathrm{Id}$.

${ }^{14}$ If the new wife ignored that her husband was already married, she can ask for the divorce; see id.

${ }^{15}$ SCC, 14 August 1994, No. 35/9. In this case, the Supreme Constitutional Court judged this provision as in conformity to the Islamic Shari'a.
} 
The $k h u l^{\prime}$ is a unilateral means of marriage breaking-off that allows women to dissolve the union in exchange of material compensation. It was known in Egyptian law, prior to 2000 , but the judge did not intervene in such procedure that took place entirely before a civil state officer (ma'dhûn). The husband's consent was always required. It was in fact some kind of amicable separation agreement or joint divorce request.

In $2000,{ }^{16}$ the legislature gave wives the possibility to go to court to get the automatic dissolution of their marriage, without the judge's power to turn their request down, even in case the husband opposes it. The declaration that she detests life with him, that continuation of married life between them became impossible, and that she fears she will not maintain the "limits of God" due to this detestation ${ }^{17}$ in case she is compelled to remain with him, is sufficient. She does not have to justify her request, nor prove its soundness. As a compensation for the husband, however, she will have to forfeit her alimony (nafaqa) ${ }^{18}$ her financial compensation $\left(m u t^{\circ} a\right)^{19}$ and to return to him the dowry that was paid at marriage ${ }^{20}$ and renounce its deferred portion (mu'akhkhar al-sadâq). ${ }^{21}$

This way of dissolving marriage is quicker to obtain than a normal judicial divorce, but the financial consequences could be heavy on the woman. The revolutionary character of Law No. 1/2000 lies in the fact that neither the husband's nor the judge's consent is necessary. In addition, the modalities of forsaking financial reimbursement were fixed by the legislature and were not left to negotiation between spouses.

The wife can, therefore, get divorced without her husband's authorization and does not have to prove the existence of harm, which equally saves her the embarrassment of exposing the intimate details of her private life before the judges. She will not have to produce two witnesses, like in all cases of judicial divorce. Moreover, the procedure is quite accelerated as opposed to a normal judicial divorce. An attempt at reconciling the two spouses has to be carried out through two arbitrators within three months maximum. ${ }^{22}$ If they could not reconcile the spouses by the end of the three-month interval and the wife still holds to her request, then the judge is bound to dissolve the

\footnotetext{
${ }^{16}$ Law No. 1/2000 concerning some rules and procedures of litigation in matters of personal status, art. 20

17 The law has quoted from Surat al-Baqara (the cow), verse 229.

${ }^{18}$ This alimony is paid for a maximum of one year after the divorce is issued; see Decree-Law No. 25/1929, art. 17 and 18. It is due to the wife, whether breaking-off the marriage took place by means of repudiation or by a judicial decision. It must cover her food expenses, clothing, housing, and medical expenses.

${ }^{19}$ Since 1985 (art. 18 bis 1 ), the wife is entitled to have a financial compensation ( $m u t^{\prime}$ ' ), which amount should not be less than two years of maintenance, and is evaluated according to the husband's financial means, divorce circumstances, and length of marriage. This compensation is only due if the marriage was broken without the wife's consent and without her being responsible for it.

${ }^{20}$ The husband-groom must pay to his bride a dowry, amount of money which is totally hers. In Egypt, the custom is to divide the dowry in two parts; the first part paid at marriage, while the second part is paid when the marriage is dissolved (either husband's death or divorce).

${ }^{21}$ Other women's rights are not reappraised. Thus, her right to children' custody is not reconsidered, nor the obligation of alimony that weighs on the husband for supporting his children (Law No. 1/2000, art. $20 \S 3$ ), nor the right to keep the house till children's custody is ended.

${ }^{22}$ Law No. 1/2000, art. 18-20. Two attempts have to be carried out if the spouses have children.
} 
marriage even if it is against the husband's will. The decision of the judge cannot be challenged.

Financially speaking, $k h u l^{\prime}$ is more advantageous to the husband than a normal request for divorce since he does not have to pay alimony, nor the financial compensation. In addition, he will be reimbursed the part of the dowry he had paid at the time of the marriage, even though it is his attitude (e.g. bad treatment or new marriage) that often led his wife to decide to break the marriage off. The divorce is final and the judge's decision is not subject to any appeal. ${ }^{23}$

Critics therefore affirmed that only rich women will be able to reimburse the dowry paid at marriage and to forsake their other financial rights. A criticism that reform advocates replied to by confirming that in many cases women are the ones who provide for their homes, and spend over their unemployed husbands. Instead of wasting time, energy and money in trying to get a judgment condemning their husbands to pay alimonies, and wasting even more time in trying to implement it, women would rather forsake their financial rights from the very beginning.

\section{B. Man's Initiative to Breaking-off Marriage: Repudiation}

The husband can end his marriage unilaterally by a simple willful declaration made before the civil state office (ma'dhûn) without the need to justify his decision, nor prove the existence of a valid reason.

The Egyptian legislature wanted to limit recourse to repudiation, but did not go as far as proscribing it, like in Tunisia. It tried to obstruct its use by putting procedural and substantive hindrances. The legislature in the 1920s required the husband's active will to repudiate his wife and deprived of any legal effects any declaration of repudiation conditional $^{24}$ or pronounced in a state of inebriation or under duress. ${ }^{25}$ This stance was contrary to the traditional Hanafi law, as codified by Qadri Pasha at the end of the nineteenth century. ${ }^{26}$ That code stipulated, in fact and expressly, that "a repudiation pronounced even under duress or by joke will produce its legal effects". ${ }^{27}$ The code likewise considered as valid "any repudiation pronounced by a husband in case of willful drunkenness caused by a forbidden drink." 28 The explanatory note of Decree-Law No. 25/1929 justified this departure from Qadri Pasha's codification by invoking better-suited solutions adopted by other schools of fiqh (following a method called takhayyur or innovative selection).

\footnotetext{
${ }^{23} I d$., art. $20 \S 5$

${ }^{24}$ Decree-Law No. $25 / 1929$, art. 2 The conditional repudiation is submitted to a condition or circumstance, or postponed to a future time.

${ }^{25}$ Id., art. 1.

${ }^{26}$ Qadri Pasha Code, Minister of Justice at the time, codified 1875 the rules of the Hanafi School relative to personal status affairs. It was never promulgated and has no legal value, but it remains a fundamental reference for judges adjudicating in the field of personal status.

${ }^{27}$ Qadri Pasha Code, art. 217.

${ }^{28}$ Id., art. 218.
} 
The Egyptian legislature also considers, since $1929,{ }^{29}$ that a triple repudiation made in one time is equivalent to a single repudiation, revocable, and not to three repudiations, irrevocable. ${ }^{30}$ Therefore, to be considered irrevocable, triple repudiation must be done in three separate pronouncements, not in one sitting. Such a stance is equally contrary to the Qadri Pasha code, where "such repudiations can be pronounced successively in three different times, when the marriage is consumed, or in the same time, whether the marriage is consumed or not."

Since $1985,{ }^{32}$ repudiation must be registered by the ma'dhûn within thirty days following the declaration; and he must inform the ex-wife through a bailiff. This notification must be made in person. Previously, it could happen that the wife would only get to know of her repudiation upon the husband's death and the opening of his inheritance will. The children eventually born after the marriage dissolution were found illegitimate. Penal sanctions are provided in case of non-observance of these procedures. Article 23 of Law No. 100/1985 stipulated a prison term of six months maximum and/or a fine not exceeding LE 200 (40 \$) imposed on the husband who would not respect such a procedure. As to the ma'dhûn, he too risks a prison term of one month maximum and a fine not exceeding LE 50 (10\$) if he infringes such provisions; he can also be dismissed or suspended of his duties for a period of one year maximum. ${ }^{33}$ Law 100/1985, however, did not challenge the very validity of the repudiation made in the absence of notification. Probably because in hanafî law there is no requirement to inform the wife of her being repudiated.

The legal effects of the repudiation start from the day of its pronouncement, except if the husband tried to conceal it. In that case, the inheritance and financial rights of the wife will not be affected until the moment the wife gets to know about her repudiation. Here again, the explanatory note of the law justifies such measure by referring to jurists from other legal schools.

Repudiation is revocable during the woman's waiting period ('idda), meaning during her first three menstrual cycles after repudiation. The spousal bond is then considered simply suspended. The husband can thus decide at any time during this term to end the separation, by words or acts. A simple resumption of spousal relations and life together is sufficient. The wife is not asked for her opinion, nor is her consent required.

Till the year 2000, the resumption of spousal relations was not registered and the law did not require that the wife should be informed. ${ }^{34}$ The husband could prove the resumption of relations with his wife, in conformity with the hanafite rules of evidence, by the testimony of two witnesses. According to Article 22 of Law No. 1/2000, in case of

\footnotetext{
${ }^{29}$ Decree-Law No. 25/1929, art. 3 .

${ }^{30} \mathrm{Id}$.

${ }^{31}$ Qadri Pasha Code, art. 224.

${ }^{32}$ Decree-Law No. 25/1929, art. 5 bis, as added by Law No. 100/1985.

${ }^{33}$ Law No. 100/1985, art. 23 bis $\S 3$.

${ }^{34}$ Qadri Pasha Code, art. 231.
} 
denial, the husband will not be able to prove that he has resumed marital relations except if he has informed his wife by an official letter before the expiration of sixty days, for a non-menopausal woman, or otherwise, within ninety days following the day of registering the repudiation. If the wife is pregnant, it is a proof of the resumption of spousal relations; as well as her recognition of the fact that she had not finished her idda period when she was informed that her husband wanted her back. If the woman denies that her husband got back to her, then he will not be able to prove otherwise except by submitting the written notification to the judge as a proof. Article 22 , however, gives the wife the right to prove by any means that spousal relations were resumed. As indicated by the explanatory note of Law No. $1 / 2000$, this provision circumvents husbands' practice of getting back their wives without their being informed, a resumption they sometimes never got to know except on the day when they sought to remarry.

At the end of the idda period and in the absence of resumption, the spousal relations are dissolved and repudiation becomes irrevocable. If the woman's husband has repudiated her only once or twice, he can remarry her by means of a new contract and a new dowry, but only if she consents to it. If she was repudiated thrice, not only does the separation becomes irrevocable, but also the husband will not be able to remarry her except if she remarries another man and then gets repudiated after the consumption of the marriage.

The legislature has thus put many barriers to repudiation. However, it did not go as far as abolishing it, nor demanded that the repudiation be pronounced before the judge and be justified by legitimate grounds, although some draft laws envisioned it. Although repudiation has been restricted, a simple unilateral declaration by the husband, nonmotivated, and made before a civil servant remains enough to instantaneously break spousal bonds off.

In case of marriage breaking-off for the man's inability to fulfill his maintenance obligation, the husband can also take back his wife during the idda period. Article 6 of Law No. $25 / 1920$ specifies that "the divorce for the inability to pay maintenance is considered a revocable repudiation and the husband has the right to take back his wife if he proves his solvency and is prepared to pay maintenance during the idda period."

Successive reforms concerning family law in Egypt have reinforced women's security and rights. Still, they remained fragmentary and only touched areas most urgently requiring a solution. Besides, the issue of their effective implementation remains extremely sensitive.

\section{Implementation of Divorce Laws}

In practice, women face a huge number of obstacles in the implementation of the rights to which they are entitled in divorce matters, whether before courts or in society.

\section{A. Difficulties in the Exercise of Rights before Courts}


In order to exercise the rights the legislature entitled the women to, they have to address a judge. ${ }^{35}$ Since 2004, Family Courts were established in order to simplify and accelerate procedures in matters dealing with the breaking-off of marriages. In practice, women face many difficulties, which are often assigned to the alleged conservatism of judges.

\section{Family Courts}

On 17 March 2004, the People's Assembly adopted Law No. 11 which established family courts. ${ }^{36}$ One of the legislature's aims through the adoption of that law was to centralize and unify matters relative to personal status and to gather all courts in charge of personal status affairs within one and the same institution called family court. This reform aimed at avoiding the scattering of the many aspects of a same case before many courts, as was the case previously, a situation that created supplementary fees and long details for dispute resolution. Women and their children were therefore expected to be the principal beneficiaries of the reform.

In practice, these family courts do not operate satisfactorily. All new buildings are not yet built and many family courts remain located in provisional premises that are often in a state of severe disrepair. Women meet quite often difficulties in getting orientations in the absence of signs to direct them at court entrance or even within the court itself.

Problems equally transpired in the implementation of Law No. 11/2004, particularly, those requiring a tentative mandatory conciliation for all divorce cases. Such a tentative must be carried out by a psychologist and a social assistant, one of the two having to necessarily be a female. An office must be at their disposal for such purpose in each family court. They normally have fifteen days to achieve a tentative conciliation between spouses, a time period deemed by experts as insufficient. In case of failure to reconcile spouses, the matter is then examined by the family court. If conciliation is reached, a record is issued, that is binding for both parties. In case of breach of the agreement, however, the parties have to start the whole procedure anew.

In practice, conciliation offices are not always installed in the family court houses because of lack of place and women have to err for a long time before finding their offices. Conciliation offices are often overwhelmed by many people, whether officers, employees, other divorcing couples, or visitors, and women find it difficult to entrust the most intimate details of their private life in such circumstances. Experts are, still, few in numbers as opposed to the number of conciliations to deal with and ill-educated to lead such tentative conciliations. ${ }^{37}$

Reading in between the lines of the 2004 Law, besides, is the idea that most spousal litigations would be trivial and that the very intervention by the expert would resolve it

\footnotetext{
${ }^{35}$ Except if they can negotiate an amicable agreement, in which case they will only register the marriage dissolution through a civil state officer (ma'dhûn).

${ }^{36}$ They were annexed to the 240 summary courts and 8 appeal courts.

${ }^{37}$ See for instance, Divorced from Justice: Women's Unequal Access to Divorce in Egypt, Human Rights Watch, 2004.
} 
streamline. However, women who end up in court often do it as a last resort, after all other means of reconciliation through closest relatives failed. Most of them, therefore, are not open to conciliation anymore. Besides, conciliation offices often try to convince women to give up their requests to avoid that it reaches courts. But if the union is a real failure, why not rather try to draw the consequences of that failure and peacefully organize the post-divorce arrangements, especially children's custody and visitation rights? It is true that in Egypt divorce often ends in a confrontation between the two parties, supported by their respective families, and an amicable divorce settlement between spouses would be exceptional.

In fact, conciliation attempts often prolong the time span. The period during which the conciliation office is engaged in settling the dispute, the judicial procedure is actually suspended. Husbands try to extend the procedure by pretending to have not received the summoning to attend the conciliation session and by not attending, a matter that leads to postponement and the need for re-notification. Sometimes, one of the experts is absent. They often do not send their reports to the judge on time, which entails delays in the examination of the case. ${ }^{38}$ The procedure produces additional fees for women. In case of reconciliation, no procedure of follow-up is foreseen and quite often the concessions accepted by one party or the other are not respected. ${ }^{39}$

\section{Conservative Judges?}

\section{a. Case Law}

Implementation of all reforms can only be achieved through the active support of judges. Although Egyptian judges have demonstrated liberalism by fighting for the respect of the rule of law and for the independence of the judiciary, ${ }^{40}$ they are sometimes accused of being more conservative in the field of family rights.

For instance, when Law No. 44/1979 was adopted and women could divorce automatically in case the husband got remarried, many judges refused to apply this provision which they considered as contrary to the Islamic Shari 'a and attacked the law for its unconstitutionality. The Supreme Constitutional Court was overwhelmed with pleas of unconstitutionality on grounds of Article 2 of the Egyptian Constitution of 1971, according to which "the principles of Islamic Shari ' $a$ are a main source of legislation." 41 " The situation got even worse when the constitution was amended in 1980 to read that the principles of the Islamic shari'a are the main source of legislation (and not merely "a" main source of legislation anymore.) Whenever judges opposed new provisions in the

\footnotetext{
${ }^{38}$ Interview with Z.E, lawyer, 2 October 2007.

${ }^{39}$ Supra note 2, Nâdia Halîm, p. 20

${ }^{40}$ See for instance, Nathalie Bernard-Maugiron, « Vers une plus grande indépendance du pouvoir judiciaire en Egypte? », Revue internationale de droit comparé, 2007; see also « Les juges et la supervision des élections de 2005 », in La fabrique des élections, Aux lieux d'être /CEDEJ, 2008, (forthcoming).

${ }^{41}$ See SCC, 4 May 1985, No. 28/2. The Supreme Constitutional Court finally declared the 1979 law unconstitutional for procedural error and not for substance (the draft-law had not been submitted to the Consultative Council, the high chamber of Parliament, in violation of constitutional article 195).
} 
personal status law, however, they did it by legal means, through pleas of unconstitutionality referred to the constitutional judge.

After the adoption of the $k h u l^{\prime}$ law of 2000 , some judges allegedly laid additional conditions on the implementation if this procedure. Some requested women to reimburse their husband the full dowry, paid and non-paid. ${ }^{42}$ Others demanded that women attend in person the hearing whereas the law does not expressly stipulate it. It seems, however, that such practices have now almost disappeared and that they were mainly due to a lack of proper legal knowledge by judges in the years following the adoption of the law.

The legislature gave judges a great discretionary power of interpretation. It is up to the judge, for example, to assess subjective notions like the harm inflicted on the wife or the existence of valid grounds for the husband's absence. He also decides the amount of alimony and assigns children's custody. Where law is silent, the judge is equally required to seek and implement the solution adopted by the prevailing opinion in the Hhnafi school. $^{43}$

It is not always easy to assess the positions taken by judges of merits in personal status cases, since their decisions are not published. An analysis of around 20 court decisions, however, cannot confirm a conservative tendency. In a case, for instance Mrs. S. S. asked for divorce for prejudice, because her husband beat and insulted her, and accused her of being a liar and a theft. According to one of her witnesses, the reason for such an attitude was the fact that she opposed her husband's intention to marry a second wife. The family court decided to divorce her for prejudice. ${ }^{44}$ In another case, the First Instance Court of Giza decided to divorce Mrs W.A because her husband beat and insulted her, married a second time and stopped spending on her. ${ }^{45}$ This decision was confirmed in appeal by Cairo Appeal Court. ${ }^{46}$ In a decision of 1999, Cairo Court of Appeal decided to confirm the decision of the Giza First Instance Court ${ }^{47}$ to divorce Mrs W. M. because she suffered a material and moral prejudice from the second marriage of her husband, who expulsed her from the matrimonial domicile to house his second wife, stopped spending on her, beat and insulted her and repudiated her before taking her back. ${ }^{48}$

As to the Court of Cassation, it gave a quite wide definition of the prejudice a woman can invoke to get a divorce, since it referred to the Mâliki school ${ }^{49}$ to consider that the prejudice can occurred through words or facts and must be considered as harming by the custom, and the wife must complain about it and not be able to bear it anymore. ${ }^{50}$

\footnotetext{
${ }^{42}$ Supra note 2, Nâdia Halîm, p. 77.

${ }^{43}$ Law No. $1 / 2000$, art. 3.

${ }^{44}$ Family Court of al-Badrashin, Case No. 806/2006, 28 June 2007.

${ }^{45}$ Giza Court of First Instance, Case No. 561/97, 25 August 1997.

${ }^{46}$ Cairo Appeal Court, No 1349/14, 26 April 1998.

${ }^{47}$ Giza First Instance Court, Case No 281/1998, 25 September 1998.

${ }^{48}$ Cairo Court of Appeal, No 1133/1 10, 4 February 1999.

${ }^{49}$ Since this cause of divorce originated in the Mâliki school, the judge will refer to the fiqh of this school to define and evaluate the prejudice.

${ }^{50}$ Court of Cassation, No 337/67, 13 October 2001.
} 
The wife can ask for separation if her husband harms her in any intentional way, whether positively through violence in words or facts, or negatively, by abandoning her bed ${ }^{51}$ It is not necessary that the prejudice be repeated, one occurrence is enough. ${ }^{52}$ The prejudice must be intentional. ${ }^{53}$ The criteria must be personal and not material, and may change according to the environment, the culture and the rank within society of the person harmed. ${ }^{54}$

Thus, judges are an important element in the process of social regulation and evolution of family practices. Far be it from simply being the mouth of the law, the judge will interpret the legal norms and exercise creative efforts. This is the case even in a field traditionally presented as pertaining to Islamic law, personal status law. ${ }^{55}$

\section{b. Recent Appointment of Women Judges}

The probably exaggerated perception of judges as conservative vis-à-vis women and their requests for marriage dissolution can be explained by the fact that, till the beginning of 2007, not one single woman was sitting in Egyptian ordinary courts. The Supreme Constitutional Court was the only court that included a woman, nominated in 2003.

This lack of female representation in courts had no legal bases. In fact, neither the Judicial Authority Law ${ }^{56}$ nor the State Council Law ${ }^{57}$ establishes any discrimination based on gender in the recruitment of judges. It only turned out that, in practice, no woman had ever filled the recruitment conditions. ${ }^{58}$

Different types of arguments had been advanced to oppose recruiting women judges. The particularly demanding working conditions in prosecution - a step necessary to accede to the position of sitting judge - would be contrary to women nature; women would not be able to work during irregular hours, particularly at night, and would be too vulnerable at the sight of blood and wounds; their families would not accept to let them go and work

\footnotetext{
${ }^{51}$ Court of Cassation, No 15/47, 2 April 1980.

${ }^{52}$ Court of Cassation, 7 January 2001.

${ }^{53}$ Court of Cassation, 11 September 2001.

${ }^{54}$ Court of Cassation, 9 January 1977.

${ }^{55}$ For a criticism of commonly held assumptions about what Islamic law is and a praxiological respecification of the meaning of Islamic law in the Egyptian context of personal status law, see Baudouin Dupret, "What is Islamic Law?", Theory, Culture and Society, 2007, 24, 2, pp. 79-100; "The Practice of Judging", in Dispensing justice in Muslim courts: Qadis, procedures and judgments, E.J. Brill (ed.), 2005, pp. 143-168 and "L'autorité de la référence", Archives de Sciences Sociales des Religions, 2004, 125, pp. 189-209.

${ }^{56}$ Law No. 46/1972, art. 38 and 116.

${ }^{57}$ Law No. 47/1972, art. 73.

${ }^{58}$ It is true that other judicial bodies included women. It was the case of the administrative prosecution, which is in charge of the instruction of disciplinary matters concerning employees and is composed of nearly one third of females. Since 1978, the State Litigation Authority, body of lawyers in charge of defending the state before courts, includes nearly $5 \%$ of women. The quality of judicial organ of those two institutions, however, is strongly contended by sitting-judges who consider that a judge's main function is to issue judgments, a matter which is not performed by those two institutions.
} 
alone several days per week in the provinces, sleep in judges hostels with other male judges; they would not be always available because of family and children obligations; they would not have enough authority to interrogate suspects or witnesses, or pronounce condemnations; men would not accept to honor judgments delivered by women.

The religious repertoire was quite obviously brandished too. The nomination of women judges would be contrary to the sharî $a .{ }^{59}$ In a decision of $1953,{ }^{60}$ the State Council had stated that no religious or legal grounds, or even women's nature would oppose the nomination of women judges, only society and its actual state of evolution. In June 2007, The Islamic Research Institute of al-Azhar refused to give a decisive opinion in this regard. It limited itself to listing the opinions of the different Islamic legal schools (madhhab, pl. madhâhib), without stating which was the right one.

In the beginning of 2007, after years of struggle of feminist groups and international pressure, thirty women were finally appointed as judges in the ordinary judiciary. Judges criticized the fact that they had not been consulted beforehand. ${ }^{61}$ The president of the Judges' $\mathrm{Club}^{62}$ added that he was against this decision at this particular time since it was not the most pressing issue in comparison with other claims of judges. ${ }^{63}$ According to a vice-president of the Court of Cassation,

[T] he timing of the raising of this issue is an attempt to divert the attention of judges away from their battle for reform and for complete judicial supervision of elections. Appointing women as judges will not offer solutions to the problems facing the judiciary but it will help the state redirect its own confrontation with judges into a superficial conflict between male and female judges. ${ }^{64}$

The president of Cairo Judges' Club declared that Egyptian society was not ready yet for the appointment of female judges. ${ }^{65}$

This stance showed the conservatism of those otherwise reformist judges and drew criticism from civil society organizations that had so far stood beside them. ${ }^{66}$ According to some observers, the government used the nomination of female judges to try to divide the Judges' Club from inside and deprive it of NGOs support. ${ }^{67}$ In March 2007, the President of the Judges' Club of the State Council also opposed the nomination of

\footnotetext{
${ }^{59}$ This did not prevent Muslim countries like Algeria, Lebanon, Morocco, Syria, Tunisia or Yemen to nominate women-judges.

${ }^{60}$ Court of Administrative Litigation, 22 Dec. 1953, No. 243/6.

${ }^{61}$ Al-'Arabî, 3 Dec. 2006; see also al-Masri al-Yûm, 3 Dec. 2007

${ }^{62}$ The Judges Club was established in 1939 to defend the collective social interests of judges but has turned into a political forum. There exist more than twenty clubs all over Egypt, but the main and most important one remains the Cairo one, to which almost all members of the ordinary judiciary and of the Public Prosecution are members (more than 9000 members).

${ }^{63}$ Al-Masrî al-Y ûm, 14 Nov. 2006. Judges have been fighting in particular since 2005 for transparent elections and judicial independence.

${ }^{64}$ Al-Ahram Weekly, 8-14 Mar. 2007.

${ }^{65}$ Al-Masrî al-Yûm, 14 Nov. 2006.

${ }^{66}$ Nahda Misr, 20 Nov. 2006; see also al-Masrî al-Yûm, 21 Dec. 2006 and al-Fajr, 6 Nov. 2006.

${ }^{67}$ Al-Fajr, 11 Dec. 2006.
} 
women judges, for mainly religious and social reasons. ${ }^{68} \mathrm{He}$ too was criticized by human rights defenders. ${ }^{69}$

Nothing guarantees, however, that the presence of women in the judiciary will improve the way women are treated before courts. Resistance to change often comes from women themselves: al-Azhar female students' protest demonstrations against the 1979 Law, that entitled women to get divorced in case their husband got remarried, and the debates regarding the adoption of the $\mathrm{khul}^{\prime}$ in 2000 showed it clearly.

\section{B. Social and Economic Obstacles}

There are often differences between the objective sought by the legislature through the adoption of a law and the practical effects of the text. This is the case with legal reforms related to divorce, which clash with social and economic obstacles.

\section{Social Obstacles}

The prevailing opinion is that the family, being the basic unit of society, must be preserved and protected even at the expense of the woman's personal feelings. A wife fighting to break off marriage will be considered responsible for destroying her home, even if her request is the result of bad treatment inflicted upon her by the husband. She will be stigmatized and sometimes rejected by her own family.

Societal conservatism and prejudices against women appeared clearly during the parliamentary debates, ${ }^{70}$ at the time of adoption of the law on the khul : Thus, one could hear deputies pretend that such a procedure would lead to a family dislocation and would have detrimental consequences on the children; that women could abuse this right and act mindlessly; that wives would give in to temptation and destroy their homes and throw their children in the streets. Another member added that this provision was a menace to the stability of the families and that it will inflame the homes. Other critics were equally raised among conservative religious circles to whom such a provision was contrary to the Islamic Shari'a, which requires the husband's consent and does not involve the judge. ${ }^{71}$ The fact that the Egyptian People's Assembly includes only a handful of women among its members ${ }^{72}$ is no doubt a factor that increased such a stance.

\footnotetext{
${ }^{68}$ Al-Masrî al-Yûm, 3 Mar. 2007.

${ }^{69}$ Rûz al-Yûsîf, 4 Mar. 2007.

${ }^{70}$ For a praxeological study of those parliamentary debates, see Jean-Noël Ferrié and Baudouin Dupret, Préférences et pertinences : analyse praxéologique des figures du compromis en contexte parlementaire. A propos d'un débat égyptien, Information sur les Sciences Sociales, vol. 43, n² 2, 2004, pp. 263-290.

${ }^{71}$ See for instance Nathalie Bernard-Maugiron, Normes et pratiques en matière de statut personnel: la loi sur le khul", Maghreb-Machrek, n¹81, 2005, pp. 77-98; see also "The Judicial Construction of the Facts and the Law. The Egyptian Supreme Constitutional Court and the Constitutionality of the Law on the Khul, in Baudouin Dupret et al, (eds)., What Happened? Telling Stories About Law in Muslim Societies, 2007, forthcoming.

${ }^{72}$ Only 4 women out of 444 members were elected at the 2005 parliamentary elections and 5 others were appointed by the President of the Republic.
} 
The social and familial pressures, therefore, are more likely inclined to dissuade women from dissolving their union, especially if they have children, even if there are valid reasons to do so. For fear of marring her reputation and her family's, a substantial number of women will not benefit from the legal reforms. Some mothers would renounce having recourse to the procedure of $k h u l^{\prime}$ because it is assumed that their daughters would not find any suitors (candidates in marriage would fear that like mother like daughter).

If a man's honor and virility are considered marred when his wife asks for divorce, ${ }^{73}$ it is even worse if she asks for $k h u l$ ? To avoid the humiliation of being "repudiated" by his wife, the husband may have recourse to his right of unilateral repudiation. On the contrary, though, husbands may push their wives to use this type of breaking-off because it is financially more advantageous. They may also accept to repudiate their wife against financial compensation. This is the "traditional" conception of $k h u l$ " that was used before 2000 to get a "divorce by agreement" in front of the ma 'dhûn. In exchange of his repudiating his wife, the husband often required that she forfeit her alimony, mut'a, mu'akkar al-sadaq but also often her list of furniture as well as the matrimonial domicile. $^{74}$

The wife is entitled to alimonies for 3 months, and to a compensation (mut'a) and to the differed part of the dowry (muakkhar al-sadaq). Even if the wife manages to get a judgment in her favour, most of the time the husband will not pay it and she will have to bring a case to court. She will wait for months to get a ruling, and then face the harshest difficulties to implement it. ${ }^{75}$

Statistics in $2002^{76}$ show that the procedure of $k h u l^{\circ}$ is a success, despite the reproaches made at the time of its adoption, that it would only be accessible to wealthy women of a certain high social standard. The number of requests for $k h u l '$ is much higher in Cairo than the number of requests for ordinary divorce. We are far from the social crisis advanced, as well as from the abusive recourse by women to this unilateral severing of marriage. Some maintain that if financial circumstances did not lead many wives to

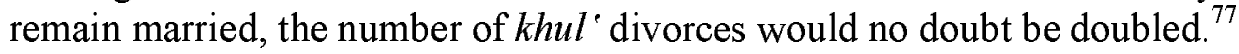

An enquiry published by the Center for Egyptian Women's Legal Assistance (CEWLA) underlines the fact that, according to judges, the number of judicial divorce claims would be in decrease in comparison with requests for khul , after the adoption of the law on $k h u l$ : This decline could be due to the fact that husbands would be more attentive to their wives' needs, now that these latter have the possibility of unilaterally breaking their

\footnotetext{
73 'Alia Shûkri, The Egyptian Woman. Between Inheritage andReality, Cairo University, F aculty of Literature, Center for Research and Social Studies, 181, 2003, p. 181 (in Arabic).

${ }^{74}$ Interview with O.Z, 2 November 2007.

${ }^{75}$ Interview with FA, lawyer, 3 October 2007.

${ }^{76}$ Supra note 2, Ahmad al-Sâwî (ed.) and Nâdia Halîm.

${ }^{77}$ Supra note 73, p. 204
} 
marriage off. ${ }^{78}$ Contrary to the most pessimistic expectations, far from kindling fire at home, khul ' could have had cohesively reinforced the family by establishing a certain equality between spouses. The fact that more and more wives participate in supporting the family could explain that middle-class and even popular women have recourse to it as well. Forsaking financial rights would not change much to the prevailing situation; on the contrary, divorce would release the wife from having to put up with the maintenance expenses of an unemployed husband.

In spite of all these obstacles, however, there has been an incremental number of divorce in Egypt by the late 1990s at the national level. ${ }^{79}$ This could be due to the dissemination of education, an increased women's awareness of their legal rights, as well as the fact that many exercise professional activities.

\section{Economic Obstacles}

Material difficulties are added to social criticism. The divorce procedure is costly. The attorney's ${ }^{80}$ fees and the court dues have to be paid. The law of 2000 tried to reduce the fees by granting maintenance claims ${ }^{81}$ free of charge, but this exemption is not extended to divorce claims. This financial obstacle could weigh on lower-class women. Some NGOs, being aware of such obstacles, have created a legal service that offers legal help free of charge to women of lower economic status. ${ }^{82}$

Whatever the kind of marriage dissolution, women will face economic difficulties in most of the cases. This is obvious, of course, il the marriage was broken off through $k h u l$, since the wife forfeits all her financial rights. Or if the wife was repudiated on her request and in exchange of financial compensation. But it is also the case in many instances of judicial divorce, where the husband does not pay his former wife her $m u t^{\prime} a$, alimony and muakkhar al-sadaq.

Besides, quite often the fathers abstain from providing maintenance to their children. According to the law of $1985,{ }^{83}$ they have to keep covering the needs of their minor children who are entrusted to their mother's custody, if they have no personal resources. In practice, few fathers pay off their financial obligation and the mothers have to provide for their children's needs from their own resources, when many can hardly recover their own alimony. A great number of ex-husbands do not pay alimonies and litigations raised against them linger for years.

Most women do not have any independent source of income and will depend on the generosity of their family and friends to survive. The most crucial problem for most of

\footnotetext{
${ }^{78}$ Hoda Zakariyya, 'The Khul', Study of Judicial Sociology'; in Ahmad al-Ṣâwî, p. 76, supra note 2.

${ }^{79}$ Nearly $30 \%$ of marriages would end up by a divorce.

${ }^{80}$ Article 3 of Law 2000 does not require assigning a lawyer for alimony claims.

${ }^{81}$ Law No. $1 / 2000$, art. 3 para. 2.

${ }^{82}$ This is, for instance, the case of the Egyptian Center for Women's Rights and the Center for Egyptian Women Legal Assistance (CEWLA).

${ }^{83}$ Decree-Law No. 25/1929, art. 18 bis $2 \S 4$, as amended by Law No. 100/1985.
} 
them is probably to find a place where to live, especially in big cities like Cairo. The law of 1985 attributes the matrimonial domicile to the wife if she has children's custody, ${ }^{84}$ but custody ends at the age of fifteen. Besides, not all women have children or children in custody age. Some of them are women whose children are grown up and who find themselves resourceless when their husband decides to repudiate them to marry a younger wife ${ }^{85}$ Moreover, in practice, women do not always manage to get the court decision entitling her to the spousal home implemented; ${ }^{86}$ especially if such a decision is delivered years after the divorce claim.

Even if they work, their salaries would hardly enable them to cover the house rent. So these women refer for support to their families who often do not have either the place or the means to accommodate extra mouths to feed. The family, itself, tries to convince the wife that her place is beside her husband, thriving to minimize the bad treatment to which she is subjected and their mothers presenting it as a normal situation for any wife. Some go and live with their married children, a situation that may have negative impact on the family life of their daughter or son. Other delay the divorce procedure or even renounce it because they would not have a place where to live. ${ }^{87}$

The lack of education and high illiteracy rate among women undoubtedly play a role in women's access to legal knowledge and the means to have such rights in fact respected. One of the woman interviewed said that it was only during the conciliation session of the procedure of $\mathrm{khul}^{\prime}$ that she got to know that she could still have the custody of her children, ask for alimonies for them from their father and keep her furniture. This was a bad surprise for the husband, who refused to cooperate further and was asked to live the place. ${ }^{88}$

\section{Conclusion}

The Egyptian personal-status law reforms have been introduced as the fruit of an internal renovation process and made legitimate by reference to sharî' $a$ principles. However limited, these reforms have nevertheless improved women's security and rights, even though they were fragmentary and only touched on issues that needed urgent solutions. Any reform attempt has been rapidly politicized and immediately led to protest and resistance. The codification and unification of norms and the improvement of women's legal status in family relations are but a first step. Undoubtedly, they offer women a legal guarantee of their rights and a remedy to end up unhappy unions. The second step, however, should be to enable them to have access to legal knowledge of their rights and to provide the environment that would enable them to use such rights and reclaim greater protection. The study of law in general, and personal status law in particular, needs

\footnotetext{
${ }^{84}$ Decree-Law No. 25/1929, art. 18 bis 3, as added in 1985 : the ex-husband has to furnish a home for his children and their custodian-mother during all the period of legal custody.

${ }^{85}$ Interview with FA, lawyer, 3 October 2007.

${ }^{86}$ Supra note 2, Nâdia Halîm, p. 66

${ }^{87}$ Interview with H. M, 4 November 2007.

${ }^{88}$ Interview with W. H., 24 October 2007.
} 
focusing more on practices. It should capture the language of law in action, and not only of law in the books. Law as a social phenomenon cannot be reduced to the mere provisions of a legal code (law on the books). ${ }^{89}$ The effectiveness of such reforms, indeed, is linked to social acceptance; one should not presume that the presence of laws is sufficient to ensure their implementation and respect. How and how far can law be a vehicle for social change when its implementation is faced by competitive religious, economic, and social norms? ${ }^{90}$

\footnotetext{
${ }^{89}$ Baudouin Dupret, "What is Islamic Law?", op.cit., p. 5.

${ }^{90}$ See for instance, Diane Singerman, Avenues of Participation, Cairo, the American University in Cairo Press, 1997; Nathan Brown, The Rule of Law in the Arab World: Courts in Egypt and the Gulf, CambridgeNew York, Cambridge University Press, 1997 and Najla Nassar, Legal Plurality: Reflection on the Status of Women in Egypt, in B. Dupret, M. Berger, and L. al-Zwainy (eds), Legal Pluralism in the Arab World, the Hague-London-Boston, Kluwer Law International, 1999, p. 191 and s.
} 